\section{Oliver Twist}

To the Editor:

William T. Lankford's “ 'The Parish Boy's Progress': The Evolving Form of Oliver Twist" (PMLA, 93 [1978], 20-32) does much to elucidate the source of what "modern critics" have termed its "problematic form": the polarization of good and evil that orders early and middle chapters of the novel seems inconsistent with the narrative's later assertion of the thieves' essential humanity, in the presentation of the consciousnesses of Fagin et al. But I am not sure that this is a real problem any more or that Lankford is talking about the true form of Oliver.

Lankford frequently refers to a "breakdown" in the original narrative mode of the novel and explains that new narratives of middle and later chapters "undermine" the moral values implicit in the novel's beginning. But in citing Dickens for a failure to achieve harmonious form, Lankford does not consider-or even mention-Oliver's original serial publication. Dickens composed his second novel for a medium in which the opportunity to develop new and more complex narrative modes is great, in part simply because the reader has time between numbers to forget the exact nature of earlier narration. And, during twenty-four or more months, the serial reader is surely more receptive to new inflections in the narrative voice than the modern reader (let alone critic), whose expectations of formal unity in fiction are not the same as Dickens' in 1837. The shifts in the nature of Dickens' narrative are not so much "breakdown" or "undermining" as intelligent use of the more than two-year length of the novel's true form.

The fact that novel reading is, after all, a temporal experience, though the words themselves may exist in a spatial framework, is one of the good things recent reader-oriented criticism has recalled for us. It is primarily when we stand back from the novel after reading it, as Lankford's article and perhaps too much modern criticism encourage us to do, and view it only in spatial terms that we are aware of a "problem" in the form of Oliver. When, on the other hand, we view the novel as a dynamic event, an "evolution" (Lankford does use the right word, it seems to me) of a structure and a narrative voice capable of presenting a complex vision of the interrelationship of good and evil, then the true form of Oliver is discovered. The "incoherence of thought and form" (p. 20) objected to by modern criticism is as much a product of our concern with esthetic consistency as a failure on Dickens' part to sustain a literary experience.
Lankford is on surer ground in complaining that a return in the concluding chapters to the novel's earlier external point of view confuses the reader's sympathy for the thieves, inspired by the narrative's direct presentation of their consciousnesses. But picking on a novel's ending is too easy; any conclusion of a fiction requires a technical trick or two whose neatness belies earlier complexity (even an author's claim that endings are artificial must itself remain artificial). I applaud Lankford's tracing of the evolving structure and narrative mode of Oliver but wish he had not suggested that Dickens threw up his authorial hands in confusion at his own creation. In the form of the conclusion, Dickens may have, as Lankford worries, allowed himself to retreat "from the consequences" of his narrative's discoveries; he may have given "in to the repression" (p. 31) of the humanity of evil in order to put some kind of end to a two-year experience. But Lankford's article also shows a development of technique that makes possible the later Bleak House, that predicts future attempts to involve the complexities of Dickens' imaginative vision in appropriate temporal as well as spatial forms.

\section{Michael Lund \\ Longwood College}

To the Editor:

William T. Lankford's article on Oliver Twist contains a number of acute observations on the relationship between theme and form in the novel. Unfortunately, however, it also contains a major misreading of a crucial episode in the book. "Monks's desire to seduce Oliver into crime," Lankford tells us, "makes the analogous threat to innocence in Harry's proposal to deflower Rose seem almost equally criminal" (p. 22). But Harry Maylie's proposal, as Dickens develops it in Chapter Xxxv, is in no way a threat to innocence and has nothing criminal about it: it is a proposal of marriage, not the proposition of a seducer. It is one of those scenes dear to the intensely class-conscious Victorian reading public, in which hero and heroine alike nobly offer to sacrifice themselves - the hero by offering marriage to a young girl of dubious parentage, the heroine by refusing to degrade the hero whom she loves by acceptance of the offer.

The situation is made absolutely clear in the conversation between Harry and his mother, in which he reveals his intention of proposing marriage to Rose (Ch. xxxiv). Mrs. Maylie, in a fruitless attempt to dissuade him, argues: "If an enthusiastic, ardent, 
and ambitious man marry a wife on whose name there is a stain, which, though it originate in no fault of hers, may be visited by cold and sordid people upon her, and upon his children also; and, in exact proportion to his success in the world, be cast in his teeth, and made the subject of sneers against him: he may, no matter how generous and good his nature, one day repent of the connexion he formed in early life."

Similarly, in the next chapter, Rose prefaces her rejection of Harry's proposal by the avowal that "Your behavior has ever been kind and noble" and continues, "As you believe that I am not insensible or ungrateful, so hear my answer." Such a response by Rose would be absurdly out of character if Dickens intended us to feel that there was anything "criminal" about Harry's proposal. To see Harry's behavior as analogous to Monks's is completely to distort Dickens' intentions. The two young men are presented as opposites: one, ultimately depraved and vicious; the other, thoroughly "generous and good." Harry Maylie is not a Steerforth, and to attempt to make him into one is to make of Oliver Twist something that it does not pretend to be.

Sidney Thomas

Syracuse University

\section{Mr. Lankford replies:}

It's a chastening pleasure at best to rectify misreadings; at least Michael Lund and Sidney Thomas raise legitimate issues while misconstruing my position.

Lund appropriates portions of my argument and offers them in criticism of it. The third paragraph of his letter muddily paraphrases the second paragraph of my paper, and his fourth paragraph much of my conclusion. Far from "citing Dickens for a failure to achieve harmonious form" or implying "that Dickens threw up his authorial hands in confusion," my essay attempted to show that the "apparent thematic and symbolic confusion is actually a progressive transformation of the novel's mode of representation" and that the "inconsistencies become coherent when seen as stages in the reorientation and development of narrative form" (pp. 20, 21). Lund misrepresents my interpretation as exactly the kind of misreading it explicitly opposes.

$\mathrm{He}$ is quite right to see that my argument calls for a temporal esthetic for both this novel and the genre. And surely serial publication predisposed many Victorian novelists toward temporal forms. I refrained from considering the issue in this paper because, although the serialization of Oliver Twist may externally justify my emphasis on the process of the novel, it is not necessarily relevant to my investigation of Dickens' adaptations and redirections of narrative form within that process. For my purposes it is sufficient that reading the novel takes time. The exigencies of serial publication dictate a different complex of questions about the novel, including biographical and psychological ones. But the mere fact of serial publication does nothing to explain how and why the particular form of Oliver Twist differs so decidedly from Dickens' other serially published novels.

One such difference is that Dickens' structuring of the action frequently reveals moral complexities that resist thematic stabilization, as in the temporary parallel of Harry Maylie and Monks. Sidney Thomas misconstrues my joke about deflowering Rose by isolating it from its context. The previous paragraphs of my essay explain that the "repeated analogies of character and action explore the unresolved relation between genteel society and the criminal underworld, but the underlying similarity between them can be exposed only at the risk of moral disequilibrium." The sentence from which Thomas quotes, when read in full, adduces the analogy between Harry and Monks as a case in which unintended implications of this device contradict the moral design: "The corrosive potential of analogy threatens to break out of control when Monks and Harry Maylie concurrently become prominent, paired by age and theatricality of speech: Monks's desire to seduce Oliver into crime makes the analogous threat to innocence in Harry's proposal to deflower Rose seem almost equally criminal" (p. 22).

This may be poorly put; certainly I agree that Dickens does not intend this analogy to undercut the contrast between the two young men. As Thomas says, "Harry Maylie is not a Steerforth"; nor is he a Wrayburn or Headstone. But Dickens has constructed a context in Oliver Twist that contains the germ of his later explorations of the situation. Character in this novel must be analyzed not in essence but in relationship. The analogy between Harry's proposal and Monks's plan is enforced not only by the pattern of similar analogies through the preceding chapters but also by the interweaving of the crucial incidents. After Harry announces his "great stake" in Rose to his mother (Ch. xxxiv), Oliver sees Monks and Fagin peering in at him through a lattice window. The next chapter begins with the fruitless pursuit of the criminals; then Harry finds Rose alone and makes his plea. Rose rejects him, and Harry, "imprinting one kiss on her beautiful forehead, hurried from the room." Rose watches from her lattice window as Dr. Losberne 